International Journal of Advanced Geosciences, 9(2)(2021) $76-87$
International Journal of Advanced Geosciences
WPC
Website: www.sciencepubco.com/index.php/IJAG
Research paper

\title{
Facies Analysis, Sedimentology and Petrographic studies of the Eocene Ameki Formation, SE Nigeria
}

\author{
Ndeze C.K. ${ }^{1}{ }^{*}$, Okoro A. U. ${ }^{2}$, Haruna K. A. ${ }^{3}$, Kalu C.G ${ }^{4}$, Afolayan O. O. ${ }^{5}$ \\ Ndeze C.K Department of Geological science Nnamdi Azikwe University Awka, Anambra State. \\ Okoro A. U., Department of Geological science Nnamdi Azikwe University Awka, Anambra State. \\ Haruna K.A Department of Geology, Alhikmah university,Ilorin Kwara State. \\ Kalu C.G., Department of Geological science Nnamdi Azikwe University Awka, Anambra State. \\ O.O Afolayan Department of Geology Univeristy of Ilorin,illorin Nigeria. \\ *Corresponding author E-mail: kndeze@gmail.com
}

\begin{abstract}
Detailed sedimentology and petrographic studies of outcrop sections of the Eocene Ameki formation exposed in the Northern depobelts of the Niger Delta was done to, characterize the sediment facies, determine the depositional environment and also to development a depositional model for the study area. Three facies associations were have been identified in the study area based on lithology, primary sedimentary structures, fossil content, geometry, lateral and vertical succession of beds and the nature of bedding contacts,and they include; brackish swamp, braided fluvial channels and Tidal creek environments. Results from polished section study showed the percentage distribution of the maceral groups as Huminite $=58.25 \%$, Liptinite $=34.35 \%$, Inertinite $=7.5 \%$. The lignites are mainly Duroclarite in nature, deposited in swamp vegetation with preserved cell structures in a slightly oxic to anoxic condition. Furthermore results from petrographic studies of representative sandstone samples showed that the predominant mineral is quartz with a greater number of them showing Monocrystalline features, while the feldspars are mostly of the plagioclase type. Ternary diagram plots for the sandstones suggest a subarkose to lithic subarkose, and Arkose to lithicarkose for the sandstones, a mixed provenance of plutonic, metamorphic and recycled sedimentary sources which are consistent with humid climatic conditions.
\end{abstract}

Keywords: Facie Analysis; Depositional Environment; Depositional Model; Petrography; Sedimentology.

\section{Introduction}

The Niger Delta occupies an area of about $75,000 \mathrm{~km}^{2}$. Geographically, the basin is situated at the Gulf of Guinea continental margin in equatorial West Africa. The frontiers of Niger Delta are defined by the Anambra basin to the north, the Cameroun volcanic line to the east, Dahomey basin lies westerly while Gulf of Guinea barricades its southern end. Its Eocene Ameki Formation is the outcropping equivalent of the subsurface Agbada Formation in the Niger Delta Basin. (Short and Stauble, 1967). The outcrops occurs in a broad belt running in a southeast trend from NW of Onitsha, Awka and Orlu Divisions to Umuahia/Bende area in Southeastern Nigeria. This Formation consists of two lithological units; a lower part of fine to coarse grain sandstones interbedded with calcareous shales and thin shelly limestone and an upper part dominated by fine of fine, grey-green sandstone, siltstone, sandy fossiliferous clays, and sandstones. This paper seeks to develop a depositional model and characterize the sediment facies based on pertrographic analysis and observed sedimentological properties.

\section{Study area}

The study area lies within the Northern updip fringes of the Niger Delta which lies between latitude $5^{0} 55^{\prime}$ ' $0 \mathrm{~N}$ and $6^{0} 10^{\prime} 0^{\prime}$ " $\mathrm{N}$ and longitude $6^{0} 35^{\prime \prime}{ }^{\prime} \mathrm{E}$ and $6^{\circ} 55^{\prime} 0^{\prime \prime}$. Some of the major towns within the study area include: Nnewi town, Ogbunike, Oba and exposures along OnitshaEnugu expressway. The locations are accessible by footpaths and shallow streams and marked with several small hills especially in the Nnewi area. The outcrop sections are accessible by foot path. They are exposed in quarries, stream channels and roadcut sections. 


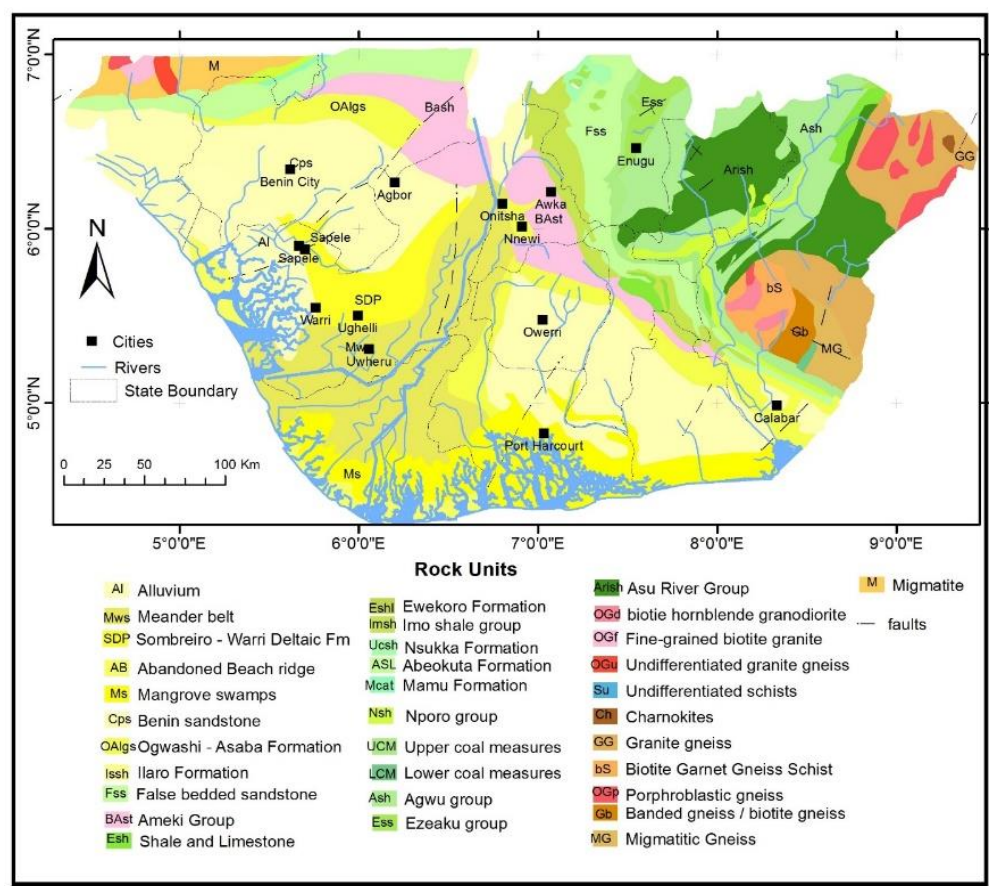

Fig. 1: Geologic Map of Nigeria Showing the Niger Delta (Redrawn and Modified After Nigerian Geological Survey Agency, 2009).

\section{Methodology}

Systematic sedimentological study and field descriptions were obtained from the 11 outcrop sections studied. Lithology characteristics, primary sedimentary structures, fossil content, geometry, lateral and vertical succession of beds and the nature of bedding contacts were observed. Also selected 35 outcrops sample were subjected to thin section study and 8 for polished section analysis.

The Selected shale and lignite samples were air dried, crushed and sieved with $2 \mathrm{~mm}$ and $1.18 \mathrm{~mm}$ mesh separately. About $20 \mathrm{gm}$ of the weight retained in the $1.18 \mathrm{~mm}$ sieve was taken to the departmental workshop for polished section preparation, and $5 \mathrm{gm}$ of the prepared sample was put inside a small rubber mould and covered with epoxy resin. This was left for 24 hours to harden before being removed and ground. Grinding was done in stages using 230, 400, 600, and 1000 carborandum grits and water on polishing machine until a flat and smooth surface was attained. The sample was polished using Magnesium oxide powder and water on Struers OPS suspension for at least thirty minutes (30min) on the polishing machine. Final polishing was done using glycerol on velvet cloth to obtain a smoother polished surface on each of the well labeled sample.

Also the selected sandstones samples were cut into slides of about $1 \mathrm{~cm}$ thick for thin sections. This starts with the impregnation of the very lose samples with Canada Balsam and Araldite resin mixtures. The mixture is poured on the sample in a plastic mould and allowed to solidify. This is done to allow cutting of slice from the loose samples.

The solidified slice of the sample is mounted on a glass slide using araldite resin as the mountant. The surface was smoothened with a carborandum grits of different grades from 90 to 400 while observing under the petrological microscope till the sample is thinned. The thinned sample was then covered with a glass cover slip using Canada balsam as the covering medium. The samples were then heated on the electric drier and left to cool in free air. The glass slides were then covered with cover slip and pressed down to remove air bubble. Excess cements were removed using Acetone and detergents.

\section{Facies analysis}

A total of five (5) facies and fifteen (13) subfacies are identified from the studied outcrop sections. Facies codes are designated to bed(s) based on their internal sedimentological features. Sub-facies are extracted from facies with variation in a particular sedimentary feature, which may infer slight variation in depositional processes. Facies code Sh is used for shale facies, SS is for sandstone, Lg is for Lignite, Cs for Claystones while Slt is for Siltstone. The sedimentary facies scheme used in the study area is modified after Miall, 1996 and is summarized in table 4.1

Table 4.1: Summary of Description and Interpretation of Lithofacies in the Eocene Strata, South-Eastern Nigeria

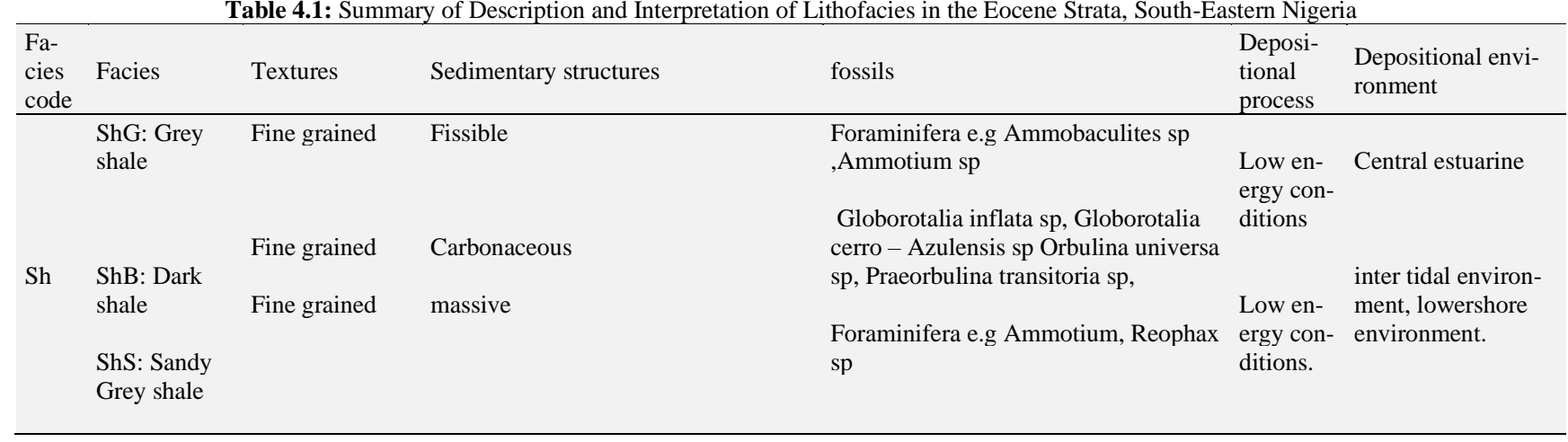




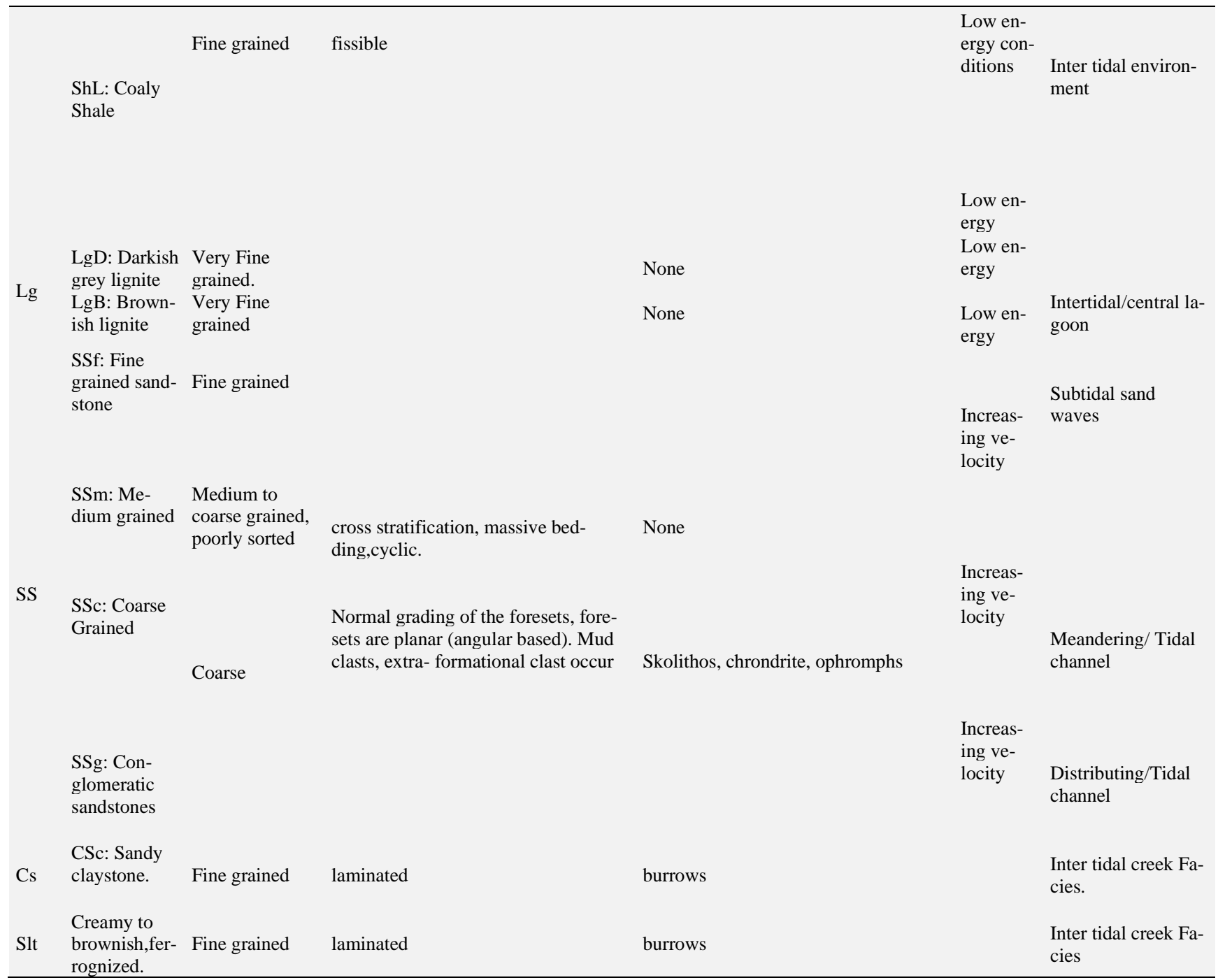

\subsection{Lithofacies description}

\subsubsection{Lignite facies}

Brownish lignite $\mathrm{LgB}$ : This variant if lignite are not as dark as the $\mathrm{LgD}$. In weight, they are a bit heavier and shows visible traces of plant imprints. They contain a lot of woody materials and are friable when very dry.

Darkish grey lignite LgD: This lignite facies type are very dark and are very light in weight.

A total of 11 lignite seams were observed in the study area. The sections include Edo spring section, Nnewi section, Akwu section, Onitsha section, Ekwulu section, Ugunzu, Oba and in the Ogbanelu stream except in the Ogbunike. The lignite seams are generally massive, dark brown in colour and occur at the middle part of the section. In Edo section, they are separated by two beds of laminated dark shale and carbonaceous massive shale. The thicker seam is about $1.3 \mathrm{~m}$ thick and occurs on a higher level than the lower seam, which is about $0.55 \mathrm{~m}$. The Akamili seam has an approximate thickness of $0.7 \mathrm{~m}$ and lies in the upper part of the section. A $1.3 \mathrm{~m}$ thick seam is exposed in the Ugunzu section of the study area, while the southernmost Ogbanelu section has a thin lignite bed of about $0.5 \mathrm{~m}$, underlain by coaly shale and capped by a grey massive shale bed .In the Nnewi section, two (2) seams occur which are separated by a shale bed. Both seams are about $1.1 \mathrm{~m}$ in thickness. One lignite seam can be observed in the Oba section, with a thickness of about 1.3 metres, the seam is exposed at the lower part of the section. A 0.83 metre seam is exposed in the Akwu section and is at the lower realm of the section, underlain by a carbonaceous black shale bed and over laid by a thick weathered sandstone unit. In Onitsha, two sections occur. At basal part of the section, and at the mid-section, the basal seam being thicker than that which occurs at the mid-section. Lignite occurs as just one seam in the Ekwulu section. This can be observed at the basal part of the seam and this about 0.6 metre thick.

\subsubsection{Shale facies (Sh)}

Grey Shale Facies (ShG): This facies are generally massive and grey coloured. They are fissible and contained foraminifera species such as Ammobaculites Sp and Ammotium Sp.

Black Shale Facies (ShB): This variants are very dark and are observed especially in the Edo sections. They are carbonaceous and were found to contain marine foraminifera species such as Globorotalia inflate Sp, Globorotalia cerro-Azulensis Sp, Orbulina universal Sp, and praeorbulina transitoria $\mathrm{Sp}$.

Sandy Grey Shale (ShS): This subfacies are grey colored, but differ from the ShG because of their sandy nature. They are massive and contain only a few foraminifera species. Although this subfacies are not very in the study area, but are well observed in the Akamili area. Coaly Shale $(\mathrm{ShL})$ : The coaly shale facies are very friable in nature. They contain a few benthic foraminifera species. They are common in the Ogbanelu outcrops. 
The shale bed thickness in the area generally ranges from 0.3 to $2.8 \mathrm{~m}$, with the thickest bed in the Nnewi section . They are essentially grey in appearance representing the ShG sub-facies or dark grey in colour representing the ShD sub-facies, which is usually indicative of organic richness. They occur as carbonaceous, sandy or coaly in texture in the sections. A total of 23 beds with varying thickness were observed in the study area.

The shale facies are exposed in all the sections of the study area. They vary in appearance from grey to dark grey in colour, massive, jointed and fractured in several places. The Edo and Ugunzu shales are carbonaceous, while the Ogbanelu shales are mostly coaly. Most of the shales are laminated.

\subsubsection{Claystone-siltstone facies}

The claystone-siltstone facies occur often simultaneously in all the sections except the Ogbanelu section. In the Edo section, claystones are observed at the base and also at the top of the section. The thickest bed is exposed in the Edo section, and they appear to be generally laminated which suggests a low energy depositional system within a floodplain or overbank. The siltstones facies are exposed in the Edo, Ugunzu, Oba and Akamili sections. They are also laminated and the thickest bed is about $1.1 \mathrm{~m}$ on the Ugunzu section.

The siltstones are generally laminated. Lamination result from changing depositional conditions that cause variation in grain size, organic composition, and mineralogical composition. It is a common feature of shale and other argillaceous rocks. Lamination provides an important clue in identifying sedimentary processes when combined with other geological evidence. In the study area, these features where observed, particularly in the claystone beds exposed in the Edo and Akamili sections, and also in the shale beds exposed in the sections. The argillaceous nature of the claystone facies coupled with the thin lamination also suggest a low energy depositional system within floodplain or overbank environment. Lack of association with any marine fauna or sedimentary features suggest a non-marine floodplain or ox bow lake environment adjacent to the braid channels (Miall, 1990; Ojo \& Akande, 2011). The claystone and siltstone facies are interpreted as floodplain deposit resulting from deposition out of suspension in an upper flow regime during flood stage (Reading, 1981; Ojo and Akande 2003).

\subsubsection{Sandstone facies}

Fine Grained Sandstones (SSF): This facies are fine grained, cross stratified and massively bedded. In some of the outcrops, they occur in a cyclic manner.

Medium Grained Sandstones (SSm): The medium grained sandstones observed in most of the outcrops show a normal grading of the foreset. The foresets are generally planar. Trace fossils are observable such as; Skolithos, chrondrite and ophromphs. They are poorly sorted, with mud clast features.

Coarse Grained Sandstones (SSc): This sandstone variant are not very common in the study area,but are observed in the Oba and Onitsha outcrops. They are usually very thin beds.

Conglomeratic Sandstones (SSg): This subfacie are very coarse and massively bedded. They occur in few of the outcrops in the study are. The clast are imbricated showing the direction of the stream flow.

In the study are, the sandstone thickness varies from $0.5 \mathrm{~m}$ to $3.9 \mathrm{~m}$ in the area. The sandstone beds appear massive, ferrognised and occur as localized cycles of coarsening upward sequence, characteristic of fluvio-deltaic deposits, which can be observed mainly in the Akamili, Ogbunike and in the Oba sections. Most of the sedimentary structures are observable in the sandstone facies especially the erosional structures such as scour and tool marks and the deformational structures.

Massive bedding is used to describe beds that appear to be homogenous and lacking internal structures. These features were mainly observed in the sandstone, siltstone and shale facies, and they indicate rapid sedimentation processes where there was no sufficient time for the structures to develop and it is usually associated with high energy flow. They were mainly observed in the sand and siltstone beds found in the study area .Most of the sandstone facies display cross bedding. These structures are very important as they serve as paleocurrent indicator, which is evidence for the direction of flow at the time the sediment was deposited, and may also be referred to as the palaeoflow. They usually appear as inclined dipping bedding, bounded by sub-horizontal surfaces. It can either be parallel cross stratified, trough cross stratified or herringbone cross stratified. These stratifications were noticeable in the study area especially in the Akamili sandstone. Graded Bedding seen in most of the outcrops. This refers to clast size variations within a bedding unit due to changes in flow strength. A bed of sand, which is formed from decelerating flow, will show a reduction in grain size from coarse at bottom to fine at the top. This pattern of clast size change in a single bed is referred to as normal grading. Conversely, an increase in flow velocity through time may result in an increase in grain size up through a bed, producing a reverse grading. Normal grading as observed in the study area is more common since most natural flows start with a strong surge followed by a gradual waning of the flow velocity.

\section{Interpretation}

Lithofacies of the shales in the study area with sub lithofacies; Greyish shale (ShG), Black shale (ShB), Sandy grey shale (ShS) and Coaly Shale (ShL) are all considered collectively here and in part as they form a closely related continuum and in part because they are subject to very similar accumulation and modification processes. These sediments are deposited under low energy conditions.

The lignite facies which include LgD: Darkish grey lignite and LgB: Brownish lignite, are also interpreted as brackish water deposits, formed under low energy conditions, based on their sedimentologic characteristics. They are mainly observed in the Oba, Nnewi and Edo sections.

The sandstone facies are observed as road cuts in the Ogbunike and as outcropping uplifts or in dried stream channels in other locations. The fine grained horizontally laminated sandstone facies (SSf) denotes upper flow-regime flatbed produced by high flow velocity as flow accelerates, but at shallow depth (Collinson et al., 2006; Nichols, 2009). The presence of parting lineation on the horizontally laminated sandstone also indicates high current velocities and suggests deposition during upper plane bed conditions (Allen, 1982). The medium to coarse grained bioturbated sandstone (SSm) may be structureless, or contain relics of planar cross beds, ripple cross lamination and horizontal bedding.

However, the coarse grained horizontally bedded sandstone may suggest a lower flow-regime flatbed produced by decelerating current; it also occurs at high flow velocity in the upper flow regime (Nichols, 2009).

The conglomeratic sandstone lithofacies represented as SSg could have been transported in suspension by the same flow which was transporting the gravels of the underlying conglomerate as bedload (Walker, 1975a). The sandstone beds may therefore represent the upper part 
of a conglomerate sandstone couplet, deposited towards the end of the discharge cycle after flow velocities had waned slightly. The generally abrupt contact between orthoconglomerate and underlying sandstone bed reflects the change from bedload rolling to suspension as the main transport mechanisms, and need not reflect sudden or large decrease in flow strengths. Based on the aforementioned interpretations, it is likely that the conglomeratic sandstone facies suggests deposition in channels. This feature are more visible in the Akamili and Oba sections.

The graded bedding of this facies (SSg) indicates deposition from a single current as the energy and flow strength diminished. The erosional base of this facies represents channel scour that was formed by avulsion at relatively high water stage (William and Rust, 1969; Miall, 1977; Yagishita, 1997). It may also imply that lithofacies SSg was deposited following a flood that eroded the strata below this facies.

CSc is a Sandy claystone facie, characterized by its creamy white to light brown on fresh surface, and massive. They are interpreted as tidal creek. They are quite common in the study area and visible in almost all the sections.

The Slt are representatives of the siltstone facies. This facies is characterised by single to double mud draped foresets, with extensive mud draped rippled toe sets that form asymptotic bottom sets and visible burrows. The parallel rhythmite layers increase or decrease in thickness throughout the section. An initial increase in thickness is observed followed by decrease in thickness and a subsequent increase in rhythmites thickness. The ripples are generated and modified in response to spring/neap tidal cycles during the migration of tidal current (Kreisa and Moiola, 1986; Shanley et al., 1992).

\section{Facies association}

The eleven sections which consist of successions showing alternating sequences of shales, lignites, claystones, siltstones, sandstones and conglomerates facies, were evaluated based on their lithology characteristics, primary sedimentary structures, fossil content, geometry, lateral and vertical succession of beds and the nature of bedding contacts. The facies associations were described as follows:

The exposed Edo spring begins with claystone at its base. This is succeeded by fine grained sandstones which pass into another claystone unit. This is overlain by a dark shale bed and is succeeded by a thin lignite bed. Overlying this is dark laminated shale which passes into a $1.2 \mathrm{~m}$ thick grey shale. This bed is overlain by yet another lignite bed which is mostly fractured in several places. This section then passes into a ferrognised laminated siltstone and finally capped by a $4.3 \mathrm{~m}$ thick claystone bed. The total thickness of the Edo section is about $15.7 \mathrm{~m}$. They are interpreted as Intertidal/central deposits (FA1) because on their fine grained textural properties and also because of the presence of brackish water foraminifera species identified such as Foraminifera e.g Ammobaculites sp, Ammotium sp Reophax sp.

The thinnest section outcrops in the Ogbanelu area which is in the southern part of the study area. This section has a total thickness of about $3.8 \mathrm{~m}$ and is composed of a thin lignite bed capped by a grayish shale bed. The shales were observed to contain a few planktic foraminifera species, however, they are predominated by the benthics species. These sediments were deposited under low energy conditions. The sedimentary features and observed foraminifera species were used to conclude that the depositional environment are also of the Intertidal/central (FA1).

The most interesting section is exposed in the Akamili stream, where we have sandstone successions which essentially shows a coarsening upward sequence. At the base is claystone bed, which is overlaid by a clayey sandstone. This is then overlaid by a thick sandstone bed. The sandstones are generally fine grained. The system terminates with a conglomeratic sandstone bed overlying the sands, which is then capped by a shale bed and a lignite bed of about $0.7 \mathrm{~m}$ thick. The total thickness of the section is $8.6 \mathrm{~m}$. The generally abrupt contact between orthoconglomerate and underlying sandstone bed reflects the change from bedload rolling to suspension as the main transport mechanisms, and need not reflect sudden or large decrease in flow strengths. These sediments interplay are suggestive of an intertidal influenced fluvial system (FA3).

The Ugunzu section consists of laminated shale at the base, overlain by dark massive carbonaceous shale, which passes into a lignite bed which is about $1.3 \mathrm{~m}$ thick. This bed is overlain by a grey massive shale which is succeed by a creamy to massive siltstone and capped by a reddish claystone unit. The total thickness of the section is $6.3 \mathrm{~m}$. Several benthic foraminifera species of the brackish water regime are also observed in the shale beds, hence the depositional environment can be inferred to be of the Intertidal/central (FA1).

The Ekwulu spring section is a $12 \mathrm{~m}$ thick section. The basal part is underlain by a lignite unit which is about $0.9 \mathrm{~m}$ thick, which is overlain by a black shale unit of about of $1.1 \mathrm{~m}$, this is overlain by thick clay stone unit of about $5.3 \mathrm{~m}$ and capped by a weathered sandstone unit of about $2.4 \mathrm{~m}$. The sediment succession are suggestive of subaerial debris flow, which are within the Meandering River environment.

The Onitsha section is about $18 \mathrm{~m}$ thick but capped with lateritic overburden of more than $2 \mathrm{metres}$. At its base is a lignite unit of about 2.1 metres, over lain by a claystone bed of $4.3 \mathrm{~m}$. This passes into a dark grey carbonaceous shale bed just about 2.1 metres in thickness. This capped by a lignite bed of 0.4 metres thick, which passes into another dark shale of 2.65 metres and overlain by a coarse grained sandstone bed which is 4.25 metres thick. The sediments succession maybe representative of two depositional cycles, with the upper part of the section representing lag deposits from minor channel fills. This are common in fluvial subtidal channel deposits (FA3). The lower parts of the section, with the grained sediments (shales, lignites and claystones) represent a second depositional cycle, and the features are consistent with Meandering River environment.

The Akwu section is similar in lithology to the Ekwulu spring section. The section is about 10metre thick. Its basal part has a carbonaceous shale bed which is about 1.3 metres thick. This is overlain by a lignite bed of just about 0.7 metres thick and capped by a weathered sandstone bed of about 6.2metres in thickness. The sediment interplay are common with subaerial debris flow and are interpreted to be deposited in Meandering River environment (FA3).

In the Nnewi section, it begins with a thin shale bed of 0.5 metres which passes into a sandstone unit of about 0.7 metres. This capped by a 1.1 metres thick lignite bed which passes into a shale bed of about 2.8 metres. This overlain by about lignite bed of about $1.2 \mathrm{metres}$ thickness, which passes into a 0.8 metres thick shale bed. This then passes into a 0.3 metres siltstone bed and overlain by a thin sandstone bed of 0.2 metres. This is overlain by a conglomerate of 2.6 metres which is capped by a siltstone of 4.1 metres. The overburden is about $4.1 \mathrm{metres}$. The sediments are interpreted to be deposited in a Shallow shoreface-offshore environment (FA2). The tidal creek deposits are characterized by symmetrical and asymmetrical shaped concave-up sandstone bodies with concentric and asymmetrical infill. Sediment infills are fine grained bioturbated sandstone (Fig 4.25 and 4.26) or heterolithic sand/silt/mud.

The Oba section is 14.3 metres thick and has at is base a carboneous shale of about 0.55 metres thick and is overlain by a lignite unit which is about 1.3 metres in thickness. This passes into a clayey siltstone unit 3.2 metres thick. It is overlain by a coarse grained sandstone bed about 3.7 metres thick. This passes into a thin bed of pebbly grained sandstone which is 0.4 metres. This overlain by 1.4 metres thick coarse grained sandstone which is about 0.6 metres thick and overlain by a thin conglomeratic sandstone about $0.2 \mathrm{~m}$ and overlain by a coarse grained sandstone bed 1.9 metres and capped by a conglomeratic sandstone of about 1.4metres and a lateritic overburden. In this section, two depositional cycles are observed. The lower section represents Intertidal/central (FA1) environment, characterized by the fine grained 
sediment. This is about 4.5metres thick, while the upper section sediment interplay depicts a Meandering River environment (FA3) environment.

The Ogbunike section has two (2). The First section which is Road cut has a total thickness of about 22 metres, while the second section, which is the quarry has a thickness of about 20 metres. Both sections consist of cyclic successions of shales, sandstones of varying textures and claystones. In the Ogbunike Quarry section, the thickest bed is a sandstone unit of about bed is about 2.3metres, while the Ogbunike road cut section, the thickest bed is about 4.2 metres.

The sediment interplay shows a depositional environment of with low energy. The fine grained interplay is interpreted to be lower shorefore (FA2) deposits, however in the upper sections of the quarry, a different depositional cycle was observed. The sediment texture varies with alternating medium to coarse grained sediments. This are feature consistent with a Shallow shoreface-offshore environment (FA2).

The lithofacies identified in the study area were further grouped into facies associations in order to interpret the environments of deposition. Three facies associations have been identified in the study area based on lithology, primary sedimentary structures, fossil content, geometry, lateral and vertical succession of beds and the nature of bedding contacts. These facies associations are interpreted as sediments deposited in the following environment of deposition: Intertidal/central, Meandering River environment to Shallow shoreface-offshore environment.

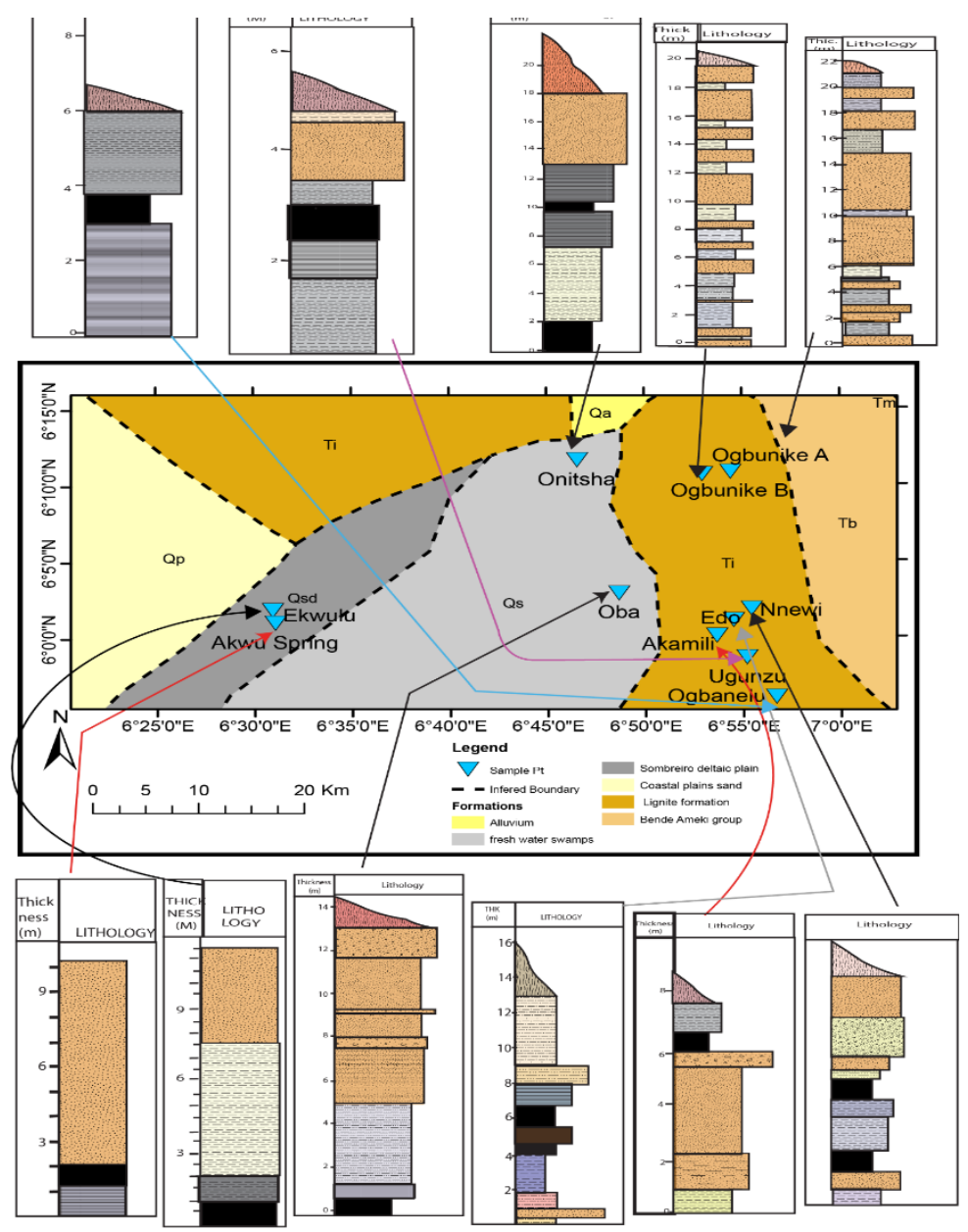

Fig. 5: Lithosections of Outcrops in the Study Area. 


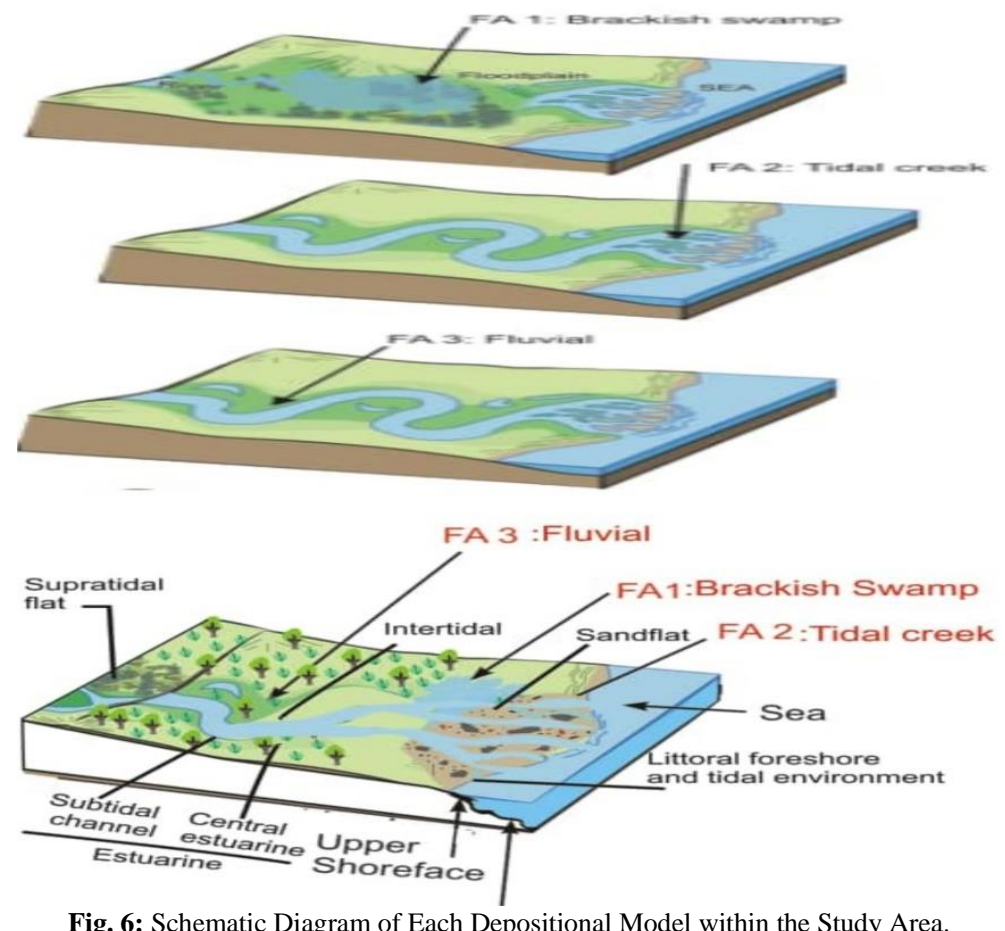

\subsection{Petrography}

\subsubsection{Sandstone petrography}

The major detrital framework components have been recalculated to $100 \%$ (Table 2) for ternary diagram (QFL) allowing them to occupy one of the three following poles.

Following the Folk's scheme (1974), for sandstone classification, the results shows that a greater portion of the samples are sub arkose in nature having between 5 to 25 percent feldspar content. Edo section sandstones are mainly subarkose, while the Akamili are predominantly sublithicarkose. In the Nnewi area, the sandstones range from Arkose to lithicarkose in nature, while the Onitsha sands are predominantly lithic arkose. In Oba area, they are sub arkose to arkose in nature, which also goes for the Ekwulu sandstones. But in the Ogbunike sections, the sandstones are mostly Arkose to lithic arkose with varying feldspar contents. The sandstone composition suggests a mixed provenance of plutonic and recycled sedimentary sources which are consistent with humid climatic conditions for the Eocene sediments using the model proposed by Suttner and Dutta (1986).

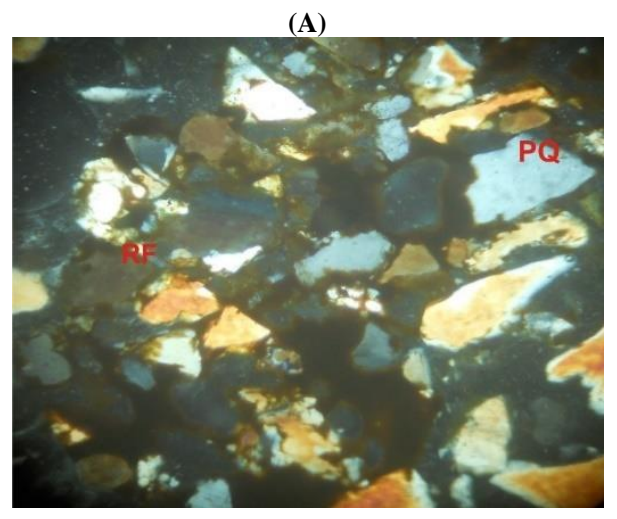

(C)

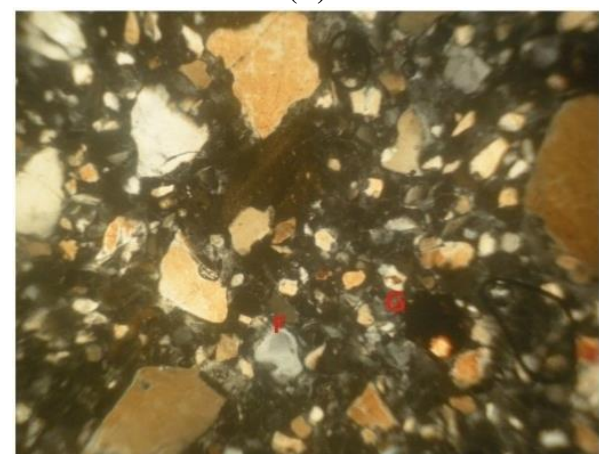

(B)

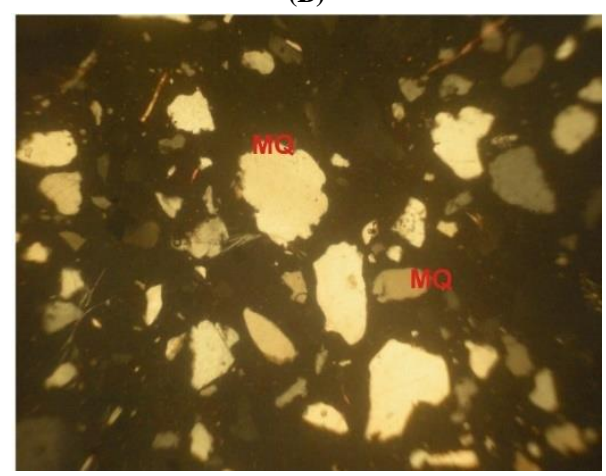

(D)

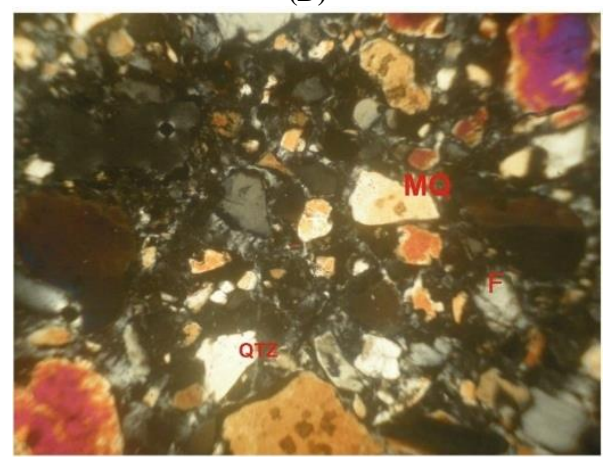

Fig. 7: Photomicrograph Showing the Mineralogical Composition and Texture Under Cross Polarized Light. MQ-Monocrystalline Quartz, Geothite, PQPolycrystalline Quartz, F-Feldspar. 
(A)

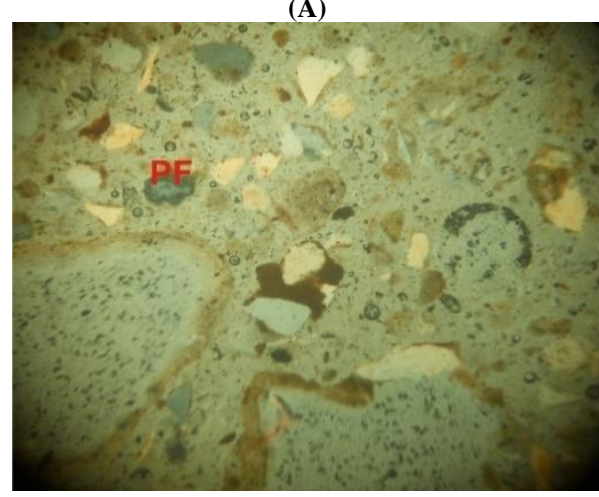

(C)

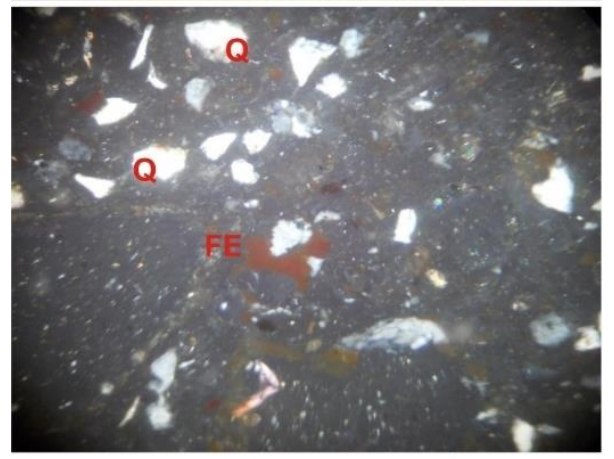

(B)

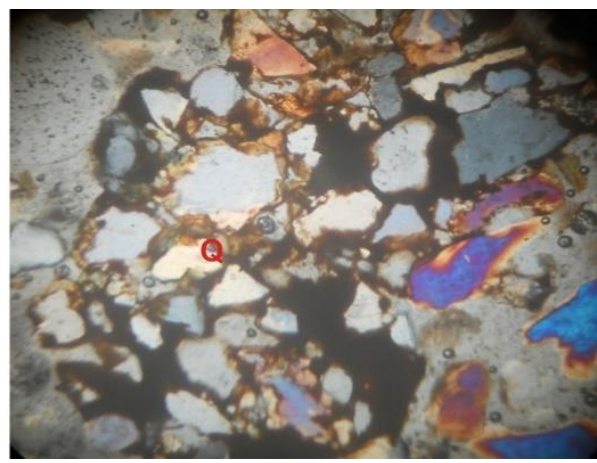

(D)

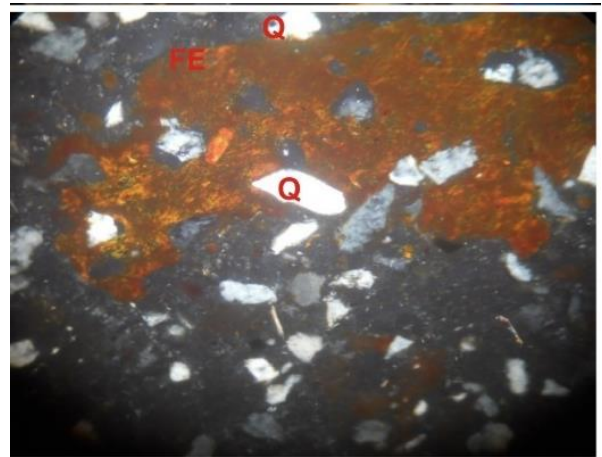

Fig. 8: Photomicrograph of Sandstone Sample Showing the Mineralogical Compositions. Q-Quartz,FE-Ferroginized Iron Minerals,PF-Plagioclase Feldspar.

Table 4.3: Quantitative Mineralogical Composition of Sandstones of Ameki Formation

\begin{tabular}{|c|c|c|c|c|c|c|c|c|c|c|c|}
\hline $\mathrm{S} / \mathrm{NO}$ & $\begin{array}{l}\text { Sample } \\
\text { No. }\end{array}$ & $\begin{array}{l}\text { Polycrys- } \\
\text { talline } \\
\text { quartz(\%) }\end{array}$ & $\begin{array}{l}\text { Monorys- } \\
\text { talline } \\
\text { quartz }(\%)\end{array}$ & $\begin{array}{l}\text { Total } \\
\text { quartz(\%) }\end{array}$ & $\begin{array}{l}\text { Plagio- } \\
\text { clase } \\
\text { feld- } \\
\text { spar(\%) }\end{array}$ & $\begin{array}{l}\text { Microcline } \\
\text { feldspar(\%) }\end{array}$ & $\begin{array}{l}\text { Total } \\
\text { feld- } \\
\text { spar(\%) }\end{array}$ & $\operatorname{Mica}(\%)$ & $\begin{array}{l}\text { Clay } \\
\text { ma- } \\
\text { trix }(\%)\end{array}$ & $\begin{array}{l}\text { Rock } \\
\text { frag- } \\
\text { ment }(\%)\end{array}$ & $\begin{array}{l}\text { geo- } \\
\text { thite }(\%)\end{array}$ \\
\hline 1 & KN 2B & 31 & 42 & 73 & 11 & 7 & 20 & 4 & 5 & 2 & 1 \\
\hline 2 & KN 2T & 29 & 40 & 69 & 18 & 9 & 27 & _ & 9 & 2 & 2 \\
\hline 3 & KN 9T & 31 & 44 & 75 & 9 & 7 & 16 & 6 & 4 & _ & 2 \\
\hline 4 & $\mathrm{KN} 12 \mathrm{~T}$ & 32 & 23 & 55 & 8 & 13 & 21 & 12 & 6 & $\overline{8}$ & 4 \\
\hline 5 & KN 13B & 27 & 41 & 68 & 10 & 6 & 16 & 7 & 3 & 7 & 2 \\
\hline 6 & KN 13T & 34 & 27 & 61 & 7 & 11 & 18 & - & 12 & 8 & 1 \\
\hline 7 & $\mathrm{KN} 35 \mathrm{~T}$ & 24 & 35 & 59 & 5 & 15 & 20 & 1 & 9 & 9 & 2 \\
\hline 8 & KN 33 & 21 & 42 & 63 & 11 & 13 & 24 & - & 7 & 4 & 2 \\
\hline 9 & KN 39B & 18 & 39 & 57 & 9 & 15 & 24 & 3 & 9 & 3 & 5 \\
\hline 10 & $\mathrm{KN} 41 \mathrm{~B}$ & 21 & 51 & 72 & 4 & 8 & 12 & 1 & 7 & 7 & 3 \\
\hline 11 & $\mathrm{KN} 41 \mathrm{~T}$ & 25 & 45 & 70 & 5 & 8 & 13 & - & 4 & 8 & 5 \\
\hline 12 & $\mathrm{KN} 44 \mathrm{~T}$ & 48 & 27 & 75 & 3 & 7 & 10 & - & 9 & 6 & - \\
\hline 13 & KN 57B & 29 & 40 & 69 & 12 & 8 & 20 & 3 & 7 & 1 & 2 \\
\hline 14 & KN 57M & 30 & 40 & 70 & 15 & 8 & 23 & - & 4 & 3 & - \\
\hline 15 & KN 57T & 24 & 37 & 61 & 9 & 19 & 28 & 2 & 5 & 3 & 2 \\
\hline 16 & $\mathrm{KN} 48 \mathrm{M}$ & 19 & 40 & 59 & 11 & 24 & 35 & - & 2 & 3 & 1 \\
\hline 17 & KN 51M & 21 & 50 & 71 & 3 & 10 & 13 & 1 & 7 & 5 & 3 \\
\hline 18 & KN 58 & 25 & 41 & 61 & 5 & 7 & 12 & 2 & 7 & 9 & 4 \\
\hline 19 & KN 61 & 32 & 37 & 69 & 11 & 9 & 20 & 4 & 3 & 3 & 1 \\
\hline 20 & KN 66 & 22 & 51 & 73 & 3 & 7 & 13 & 1 & 8 & 6 & 2 \\
\hline 21 & KN 67M & 33 & 30 & 63 & 12 & 8 & 20 & 6 & 6 & 3 & 2 \\
\hline 22 & KN 67T & 29 & 44 & 73 & 10 & 6 & 16 & 2 & 5 & 2 & 2 \\
\hline 23 & KN 69M & 36 & 39 & 75 & 8 & 13 & 21 & - & 3 & 1 & - \\
\hline 24 & KN 77 & 40 & 39 & 79 & 5 & 8 & 13 & 1 & 4 & 3 & - \\
\hline 25 & KN 79 & 25 & 36 & 61 & 6 & 17 & 23 & 2 & 9 & 4 & 1 \\
\hline 26 & KN 82B & 32 & 28 & 60 & 11 & 7 & 18 & 3 & 7 & 8 & 4 \\
\hline 27 & KN 86 & 23 & 33 & 56 & 9 & 14 & 23 & 5 & 9 & 4 & 3 \\
\hline 28 & KN 88M & 22 & 49 & 71 & 5 & 8 & 13 & 4 & 7 & 3 & 2 \\
\hline 29 & KN 92B & 44 & 29 & 73 & 5 & 7 & 12 & - & 10 & 3 & 2 \\
\hline 30 & KN 94M & 24 & 27 & 51 & 12 & 16 & 28 & 7 & 7 & 3 & 4 \\
\hline
\end{tabular}



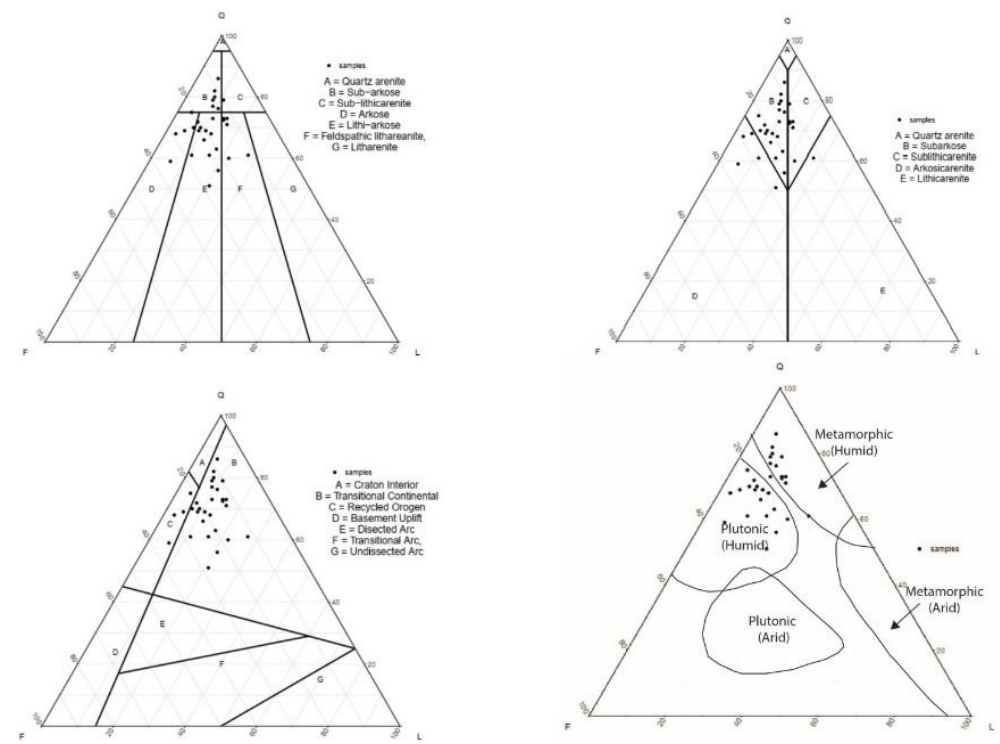

Fig. 9: Ternary Plots for Classification of Sandstone of the Eocene Formation (Redrawn and Modified After Folk, 1974).

\subsubsection{Maceral study}

Many of the shapes and structures observed within macerals can be related to specific plant organs, plant genera and species. The petrographic composition of coal has been studied in detail, in order obtain a facies classification and to deduce the paleoenvironments during peat deposition. The percentages of the maceral groups, huminite, inertinite and liptinite have been plotted in ternary diagrams in order to provide the basic information on lignite deposition (Figure $10 \& 11$ ). The lignites from the Eocene, Ameki Formation generally consist of high amount of huminite, with lesser amounts of liptinite and inertinite macerals (Figure 12). They can be classified as duroclaritic in nature (Figure 13) and deposited in swamp vegetation with preserved cell structures in a slightly oxic to anoxic conditions.
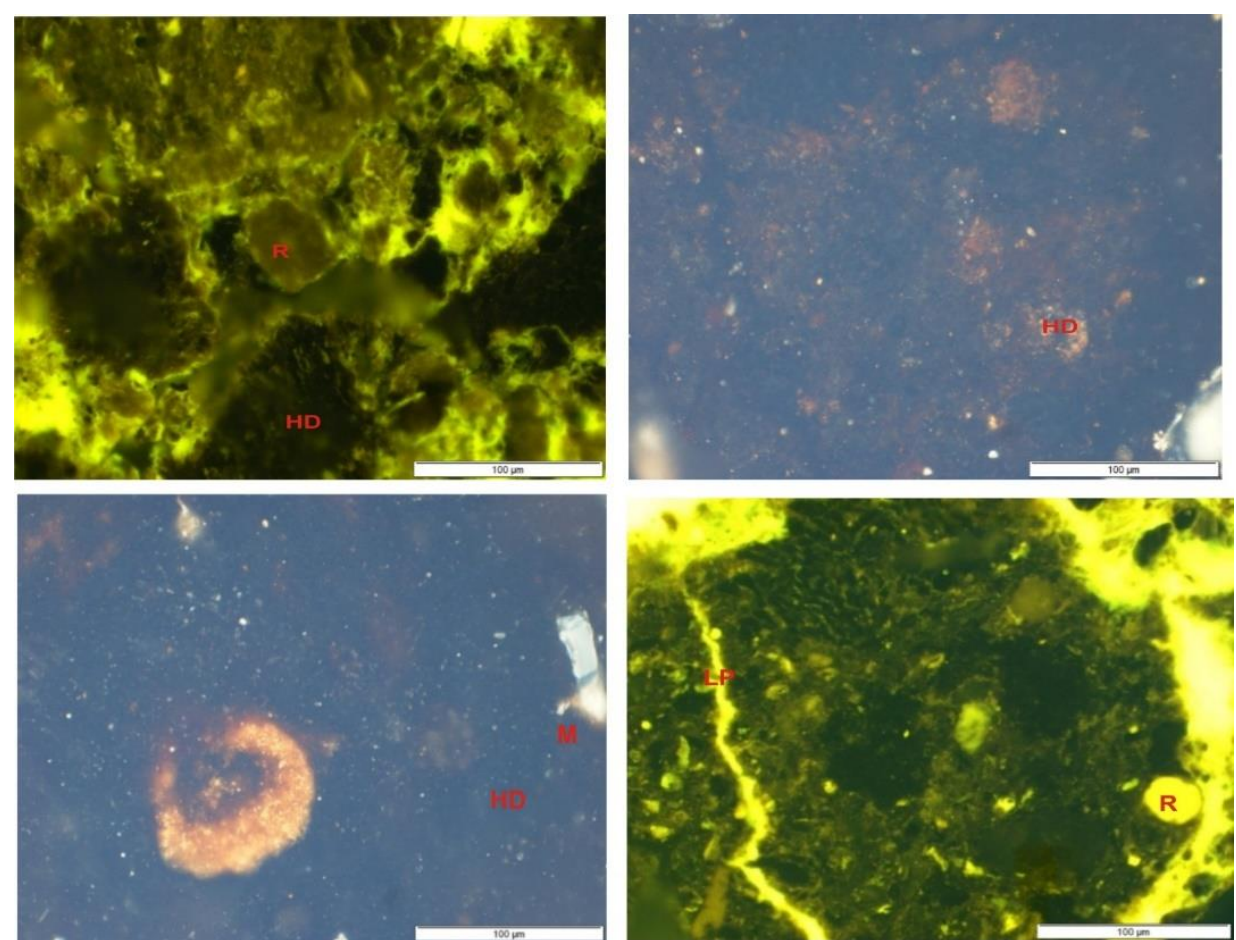

Fig. 10: Photomicrograph of Samples in Ultraviolet Light and Reflected Light Showing Several Aggregates of Humodetrinite Intergrown with Liptodetrinite Grains. 

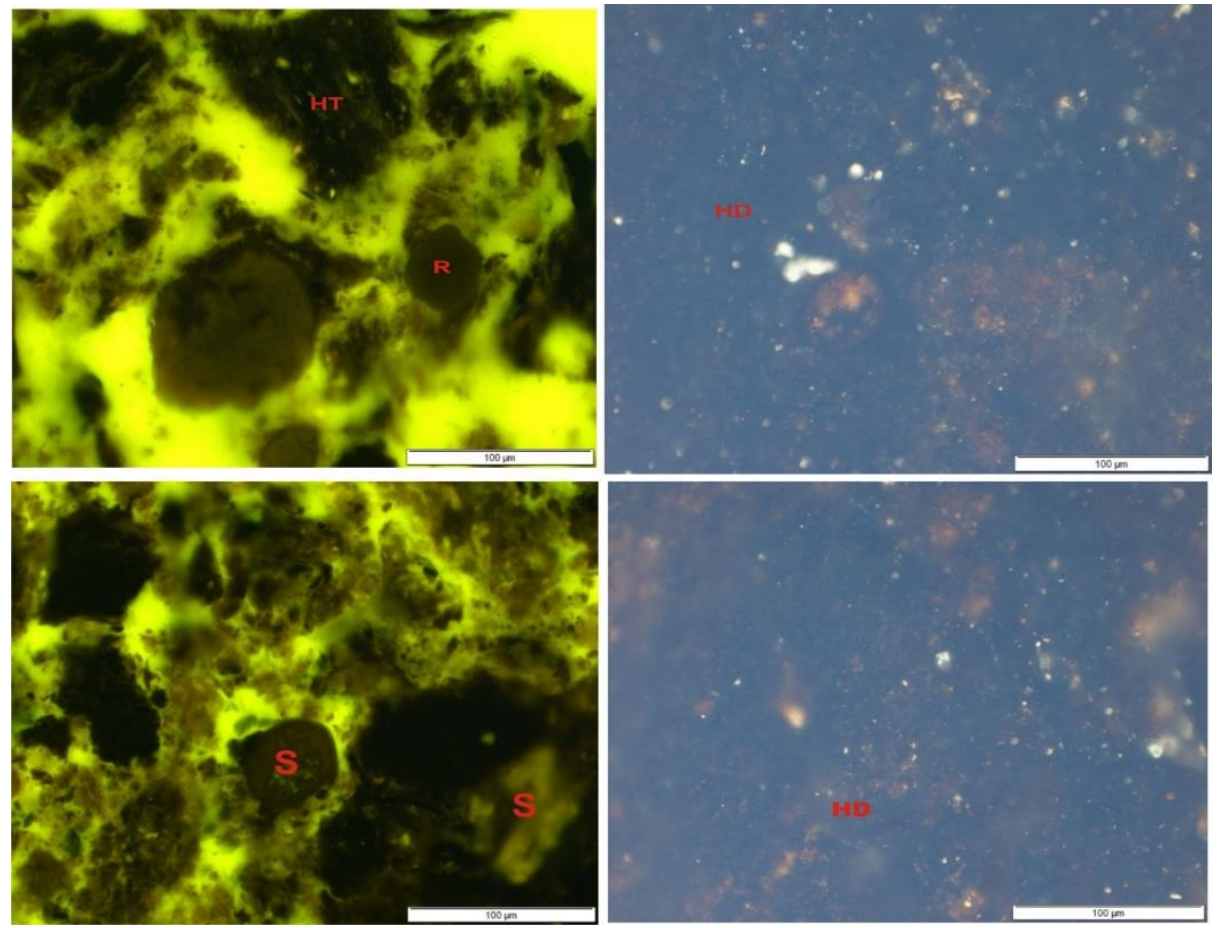

Fig. 11: Photomicrograph of Samples in Reflected Light and in Ultraviolet Light Showing Clouds of Humodetrinite (Lower Right Corner) and Mineral Matter - M (Lightly Reflecting White Grains) are Distributed Throughout the Photo.
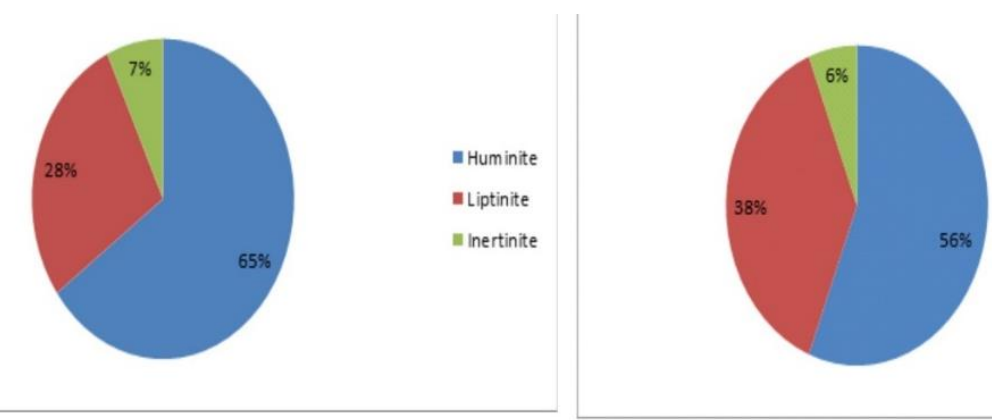

\section{Muminite}

- Liptinite

Inertinite
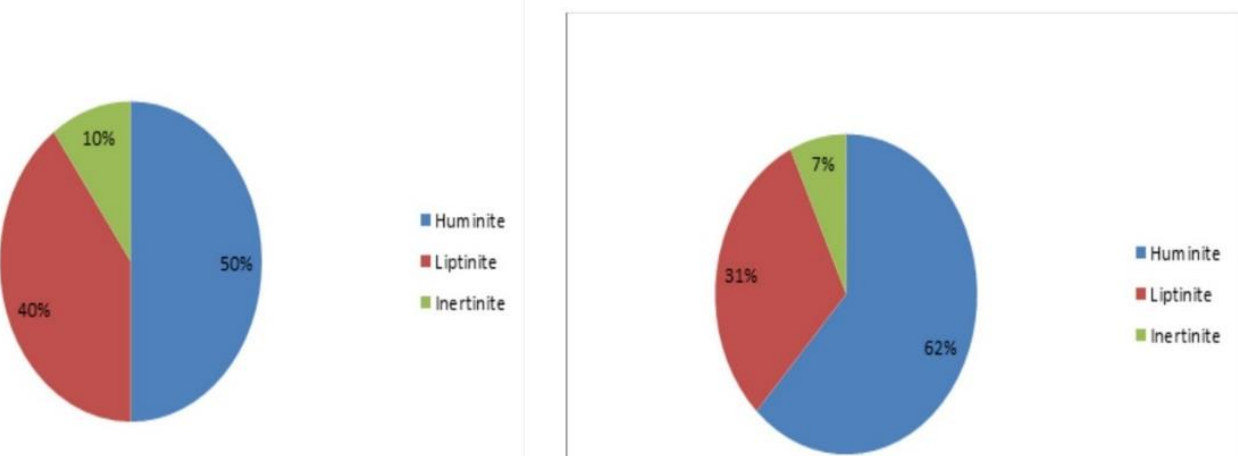

Fig. 12: Pie Chart Representing the Maceral Percentages Present, as Observed from Samples Studied. 


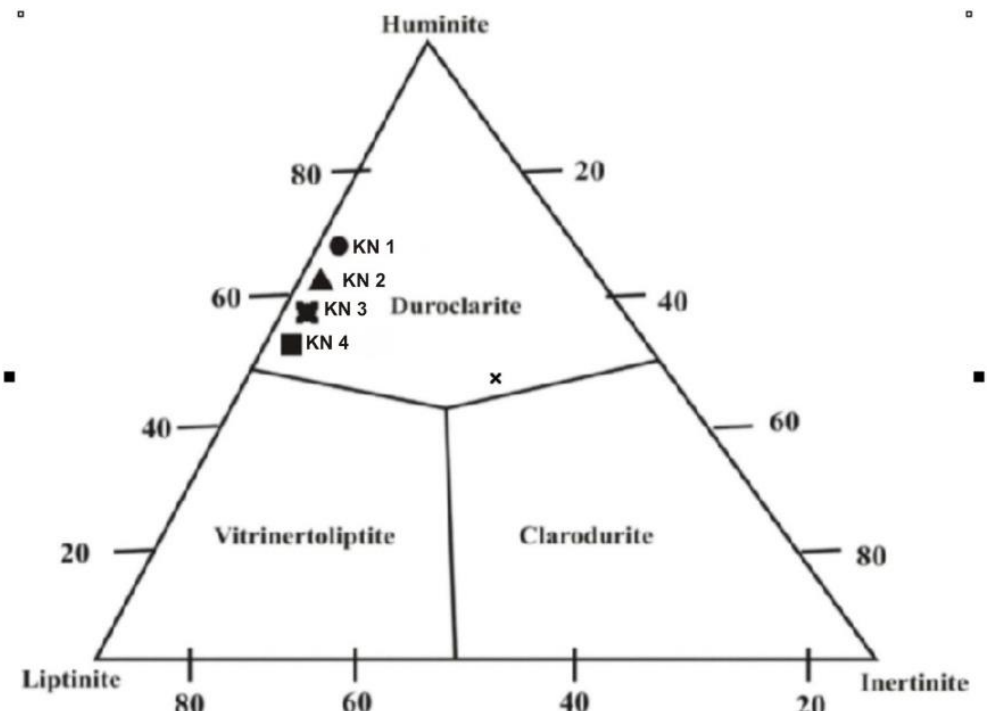

Fig. 13: Ternary Plot of the Three Major Maceral Groups Identified in the Study Area, Showing the Duroclaritic Nature of the Constituents on the Basis of Principal Microlithotypes Classification of Coal (Modified from Bustin 1983).

\section{Conclusions}

Facies analysis, Sedimentology and petrography study of outcrop sediments of the Eocene Ameki formation in the Niger delta were studied and the results indicate the following;

1) The lithofacies identified in the study area were further grouped into facies associations in order to interpret the environments of deposition. Three facies associations have been identified in the study area based on lithology, primary sedimentary structures, fossil content, geometry, lateral and vertical succession of beds and the nature of bedding contacts. These facies associations are interpreted as sediments deposited in the following environment of deposition: brackish swamp, braided fluvial channels and Tidal creek.

2) Results from petrographic studies of representative sandstone samples shows that the predominant mineral is quartz with a greater number of them showing Monocrystalline features, while the feldspars are mostly of the plagioclase type. Ternary diagram plots for the sandstones suggest a subarkose to lithic subarkose, and Arkose to lithicarkose for the sandstones, a mixed provenance of plutonic, metamorphic and recycled sedimentary sources which are consistent with humid climatic conditions.

3) Results from polished section study shows the Huminite maceral group as having the highest percentage .Ternary plots for the lignites distribution as to permit depositional environment places it as Duroclarite in nature, deposited in swamp vegetation with preserved cell structures in a slightly oxic to anoxic condition.

\section{Acknowledgment}

This paper reports on parts of the PhD thesis completed by Kennedy Ndeze at the Nnamdi Azikwe University Awka Anambra State Nigeria. The authors thank the department of Geology University of Ilorin for their assistance provided in the petrographic studies. The authors however take full responsibility for the ideas and interpretations presented in the paper.

\section{References}

[1] Allen, J. R. L., (1982). Developments in Sedimentology, Sedimentary Structures, their character and physical basis, volume II. Volume 30, part B, Elsevier, Amsterdam, p663.

[2] Avbovbo, A.A., (1978). Tertiary lithostratigraphy of Niger delta. AAPG Bull. 62, 295-300. https://doi.org/10.1306/C1EA482E-16C9-11D7$8645000102 \mathrm{C} 1865 \mathrm{D}$.

[3] Collinson J, Mountney N., Thompson D., (2006). Sedimentary Structures (Harpenden 2006)

[4] Ekwenye, O.C., (2014). Facies architecture, sedimentary environment and palaeogeographic evolution of the Paleogene stratigraphy, South-eastern Nigeria. Unpublished Ph.D thesis, Royal Holloway, University of London, p544.

[5] Ekwenye, O.C., Nichols, G.J., Collinson, M., Nwajide, C.S., Obi, G.C., (2014). A paleogeographic model for the sandstone members of the Imo Shale, South-eastern Nigeria. Journal of African Earth Sciences 96, p190-211. https://doi.org/10.1016/j.jafrearsci.2014.01.007.

[6] Ekwenye, O.C. Nichols, G., Mode, A. W., (2015). Sedimentary petrology and provenance interpretation of the sandstone lithofacies of the Paleogene strata, south-eastern Nigeria. Journal of African Earth Sciences 109, p239-262. https://doi.org/10.1016/j.jafrearsci.2015.05.024.

[7] Folk, (1974). Petrology of Sedimentary Rocks: Austin Hemphill Publishing Company, p182

[8] International Committee for Coal Petrology, (ICCP), (1971). International Handbook of Coal Petrography, 1st Supplement to 2nd Edition. CNRS (Paris).

[9] International Committee for Coal Petrology, (ICCP), (1975). International Handbook of Coal Petrography, 2nd Supplement to 2nd Edition. CNRS (Paris).

[10] Jan du Che^ne, R., Onyike, M.S., Sowumi, M.A., (1978). Some new Eocene pollen of the Ogwashi-Asaba Formation, South eastern Nigeria. Revista de Espanol Micropaleontologie 10, p285 - 322.

[11] Kreisa R, D and Moiola R. J., (1986). Sigmoidal tidal bundles and other tide - generated sedimentary structures in the Curtis Formation, Utah. Geological Society of America Bulletin 97: p381 - 387 https://doi.org/10.1130/0016-7606(1986)97<381:STBAOT>2.0.CO;2.

[12] Miall, A. D., (1977). Lithofacies Types and Vertical Profile Models in Braided River Deposits: A Summary. In: Miall, A. D., Ed., Fluvial Sedimentology, Geological Survey of Canada, Calgary, p597 - 604.

[13] Miall A. D., (1990). Principle of Sedimentary Basin Analysis. Springer - Verlag, New York, p667 https://doi.org/10.1007/978-1-4757-4235-0.

[14] Middleton, G. V., (1973). Johannes Walther's Law of Correlation of Facies. Geological Society of America Bulletin, 84, $979-988$. https://doi.org/10.1130/0016-7606(1973)84<979:JWLOTC >2.0.CO;2. 
[15] Nigerian Geological Survey Agency, (2009). Geological Map of Nigeria. Published by the Authority of the Federal Republic of Nigeria.

[16] Nichols, G., (2009). Sedimentology and Stratigraphy. $2^{\text {nd }}$ Ed. Blackwell Publishing Oxford, United Kingdom, p419.

[17] Ojo, O. J and Akande, S. O., (2011). Sedimentology and Depositional environments of the Upper Cretaceous sediments in the Share - Lafiagi area, Northern Bida Basin. Nigeria Mining and Geosciences Society (NMGS) Annual International Conference, Nsukka, Abstract vol., p. 52 - 53

[18] Ojo, O. J and Akande, S. O., (2011). Facies Relationships and Depositional Environments of the Upper Cretaceous Lokoja Formation in the Bida Basin, Nigeria. Journal of Mining and Geology, 39, p39 - 48. https://doi.org/10.4314/jmg.v39i1.18789.

[19] Shanley, K.W., McCabe, P.J., (1993). Alluvial architecture in a sequence stratigraphic framework: a case history from the Upper Cretaceous of southern Utah, U.S.A. In: Flint, S., Bryant, I. (Eds.), Quantitative Modelling of Clastic Hydrocarbon Reservoirs and Outcrop Analogues, vol. 15. Int. Assoc. Sedimentol., Spec. Publ., p21-55 Shell Companies in Nigeria, 1997. Shell Companies in Nigeria, 1997, Reservoir Geology. https://doi.org/10.1002/9781444303957.ch2.

[20] Short, K. C. and Stauble, A. J. (1967). Outline of Geology of Niger Delta. Bulletin of American Association of Petroleum Geologist p761-779.

[21] Suttner, L. J., Dutta, P.K., (1986). Alluvial sandstone composition and paleoclimate, I. Framework mineralogy, Journal of Sedimentary Research 56, p329-345. https://doi.org/10.1306/212F8909-2B24-11D7-8648000102C1865D.

[22] Walker R. G., (1975). Generalized Facies Model for Resedimented Conglomerates of Turbidite Association. GSA Bulletin (1975) 86 (6): 737 - 748 https://doi.org/10.1130/0016-7606(1975)86<737:GFMFRC>2.0.CO;2.

[23] William, P. F and Rust, B. R., (1969). The Sedimentary of a braided river; Journal of Sedimentary Petrology, v. 39, p649 - 679 https://doi.org/10.1306/74D71CF3-2B21-11D7-8648000102C1865D.

[24] Yagishita, K., (1997). Paleocurrent and fabric analysis of fluvial conglomerate of the Paleogene Noda Group, Northeast Japan. Sed. Geol. V. 109, p.53 - 71. https://doi.org/10.1016/S0037-0738(96)00058-9. 